\title{
THE ECOLOGY OF TRANSLATION, OR, The TransLator as World Author
}

\section{Alex Ciorogar ${ }^{*}$}

\begin{abstract}
In the last couple of decades, digital processes have accelerated what we typically call globalization. In contemporary scholarly literature on translation, then, the understanding of translators as relational agents has continually evolved. Scholars have, indeed, considered the importance of translators for the field of literary studies, but an ecological approach unfortunately remains absent in current research, since academics have relied either on deconstructive or pragmatist accounts of translation. Rather than passive mediators, then, I contend that translators represent an essential aspect of world authorship, thus examining the role of translators as a defining element of contemporary global culture.

Keywords Translation studies, authorship, ecology, world literature, globalization, digitalization.
\end{abstract}

\section{Introduction}

In the last several years, developments in digital technologies have continuously amplified the processes of globalization. ${ }^{1}$ As a result of constant discussions about the central role of what we typically call 'the interface' or relationality, ${ }^{2}$ current

* Babeş-Bolyai University of Cluj-Napoca. alexandru.ciorogar@ubbcluj.ro.

DOI: 10.26424/philobib.2021.26.2.12

This work was supported by a grant of the Romanian Ministry of Education and Research, CNCS - UEFISCDI, project number PN-III-P4-ID-PCE-2020-2006, within PNCDI III.

1 See Dal Yong Jin (ed.), The Routledge Handbook of Digital Media and Globalization (New York: Routledge, 2021); and Dal Yong Jin, Globalization and Media in the Digital Platform Age (New York: Routledge, 2019).

${ }^{2}$ Lori Emerson, Reading Writing Interfaces. From the Digital to the Bookbound (Minneapolis \& London: University of Minnesota Press, 2014); Patrick Jagoda, Network Aesthetics (Chicago: 
research has continuously emphasized and transformed the understanding of translators as interactive agents to the point that it has simply now become something of a cliché. However, even if "the concept of authorship has always been a central question in theoretical discussions on translation, ${ }^{3 \prime}$ the idea that translators themselves ought to be recognized as genuine authors with actual rights still remains a grossly underdeveloped one.

When defining the status of translators, specialists have generally relied on either deconstruction or pragmatist accounts. Under the influence of poststructuralist intertextuality, some academics have tried, on the one hand, to highlight the importance of invisibility in the task of cultural and linguistic transference, ${ }^{4}$ while others have inversely emphasized the value and towering role of visibility in the process of creatively rewriting original works. ${ }^{5}$ It seems, then, that scholars have, indeed, closely considered the importance of translators for the field of authorship studies, without, however, having really granted translators the status they nevertheless deserve. It is true that the quarrel over the visibility and invisibility of translators stems from a discussion absorbed with status rather than practice, but, in order to fully understand the role of translators in the age of digital globalization, ${ }^{6}$ I will suggest that we must adopt a new ecological approach, which, as I will try to show, could also benefit the field of World Literature studies. ${ }^{7}$

Chicago University Press, 2016); Nicolas Bourriaud, Relational Aesthetics, transl. by Simon Pleasance, Fronza Woods and Mathieu Copeland (Dijon: Les Presses du reél, 2002).

3 Claudia Buffagni, "Towards a New Definition of the Translator's Role," in Claudia Buffagni, Beatrice Garzelli, Serenella Zanotti (eds.), The Translator as Author. Perspectives on Literary Translation (Berlin: Lit Verlag, 2011), 15.

${ }^{4}$ Barbara Cassin has put forth one of the most influential postmodern or deconstructionist definitions of translation. Cassin has defined the idea of untranslatability as an infinite process of rewriting related, of course, to the instability of signification. See Barbara Cassin, Dictionary of Untranslatables. A Philosophical Lexicon (New Jersey: Princeton University Press, 2014).

5 See Anthea Bell, "Translation: Walking the Tightrope of Illusion," in Susan Bassnett, Peter Bush (eds.), The Translator as Writer (London \& New York: Continuum, 2007), 58-59.

${ }^{6}$ Amy J. Elias, Christian Moraru (eds.), The Planetry Turn: Relationality and Geoaesthetics in the Twenty-First Century (Illinois: Northwestern University Press, 2015); Ulrich Beck, Risk Society. Towards a New Modernity, transl. by Mark Ritter, (London \& Newbury Park, Calif.: SAGE, 2009 (1992). First published in 1986 in German; Yann Moulier-Boutang, Cognitive Capitalism (Cambridge: Polity, 2011); Liam Young, Machine Landscapes: Architectures of the Post Anthropocene (New Jersey: John Wiley \& Sons, 2019).

7 Franco Moretti, Graphs, Maps, Trees. Abstract Models for a Literary History (New York: Verso Books, 2005); Franco Moretti, "Conjectures on World Literature" in New Left Review, no. 1, January-February, 2000, 54-68; Franco Moretti, "More Conjectures" in New Left Review, no. 20, March-April, 2003, 73-81; Pascale Casanova, Le République mondiale des Lettres (Paris: Les Éditions du Seuil, 1999); David Damrosch, What is World Literature? (New Jersey: Princeton University Press, 2003); David Damrosch, How to Read World Literature (New Jersey: Wiley- 
My assessment sustains that, far from being simple mediators in the practice of cultural migration ${ }^{8}$, translators actually play an essential role in what has been recently coined 'world authorship, ${ }^{9}$ ' a defining element of contemporary global culture and the dynamics of international literary forms. ${ }^{10}$ No work has yet confronted the question of the translator in these terms, even though ecology and literature have been correlated in many different ways in the past couple of decades. $^{11}$

\section{The Real, The Textual, The Imaginary}

In what appears to be a clear Benjaminian fashion, ${ }^{12}$ the moral task of the translator has been lately (re)described as that of making sure the literary work survives its own extinction. The translator's subjective and creative work of interpretation subsequently bears certain ethical responsibilities. ${ }^{13}$ However, in order to discuss the figure of the translator as an author, one needs to simultaneously account for all the dimensions involved in the activity or experience of negotiating the textual and aesthetic differences or similarities between distinct civilizations. Using Alexander Gefen's grouping of authorial issues, I would therefore like to propose a conceptual

Blackwell, 2009); David Damrosch (ed.), World Literature in Theory (New Jersey: Wiley Blackwell, 2014); Pheng Cheah, What is a World? On Postcolonial Literature as World Literature (Durham, N.C.: Duke University Press, 2016); Sharae Deckard et al., Combined and Uneven Development: Towards a New Theory of World-Literature (Liverpool: Liverpool University Press, 2015); Ben Etherington, Jarad Zimbler (eds.), The Cambridge Companion to World Literature (Cambridge: Cambridge University Press, 2018).

8 See Rob Schwartz, Nicholas de Lange, "A Dialogue: on a Translator's Interventions," in Susan Bassnett, Peter Bush (eds.), The Translator as Writer (London \& New York: Continuum, 2007), 13-17.

${ }^{9}$ Rebecca Braun, "The World Author in us All: Conceptualising Fame and Agency in the Global Literary Market" in Celebrity Studies, vol. 7, 2016, 457-475; Rebecca Braun, "Introduction: The Rise of the World Author from the Death of World Literature" in Seminar: A Journal of Germanic Studies, vol. 51 no. 2, 2015; Adriaan van der Weel, "Literary Authorship in the Digital Age" in Ingo Berensmeyer, Gert Buelens, Marysa Demoor (eds.), The Cambridge Handbook of Literary Authorship (Cambridge: Cambridge University Press, 2019), 218-234.

${ }^{10}$ See Theo D'haen, César Domínguez, Mads Rosendahl Thomsen (eds.), World Literature. A Reader (New York: Routledge, 2012).

${ }^{11} \mathrm{See}$, for example, Alexander Beecroft, An Ecology of World Literature. From Antiquity to the Present Day (London \& New York: Verso Books, 2015).

12 Walter Benjamin, "The Taks of the Translator" in Marcus Bullock and Michael W. Jennings (eds.), Walter Benjamin. Selected Writings. Volume 1. 1913-1926 (Massachusetts: Harvard University Press, 2002), 253-263.

13 Claudia Buffagni, Beatrice Garzelli, Serenella Zanotti, "Introduction," in Claudia Buffagni, Beatrice Garzelli, Serenella Zanotti (eds.), The Translator as Author. Perspectives on Literary Translation (Berlin: Lit Verlag, 2011). 
analogy in that the idea of the translator (or, as we will later see, translational ecosystems) could be successfully and carefully mapped through the use of the following categories: ${ }^{14}$

1) The Real: the actual historical individuals and non-human entities (such as a laptop, to name just one ordinary token) involved in translating a text; 2) The Textual: the unified poetic voice in a text, for instance, or the cohesive stylistic attitudes of the fictional speaker, and, last but not least; 3) The Imaginary: the function of the translator (the social or public acknowledgment of that cultural construct). ${ }^{15}$ The translator's posture or subject-positions and the ways in which the translational ecology proceeds or succeeds in (re)producing the expressive tonalities of a text determines the extent to which the name of the translator might represent-in a Foucauldian sense-a valid or invalid principle of valorisation and classification of those literary translations. Replicating a classification formerly suggested by Dominique Maingueneau, ${ }^{16}$ this taxonomy is extremely valuable not only when developing a vision of the various types of discourses involved in contemporary theoretical debates surrounding the figure of the translator, but also when examining the particular practices of translation. It also allows us to leave behind the previously mentioned and worn-out dichotomy that has been haunting the field of translation studies for the last couple of decades or so. In addition, then, moving beyond both the overindulgent postmodern dissipation of translation practices and the unwilful refusal of pragmatic and analytical philosophy to grant the translator cognitive rights would necessitate a swift rethinking of the stages of cultural transposition. ${ }^{17}$ The translator is involved in all three phases of the interpretive process: 1) pre-production, 2) re-production per se, and, finally, 3) postproduction. Each step is governed by a series of rules, norms, methods, and standards.

\footnotetext{
${ }^{14}$ See Alexandre Gefen, "L'auteur, une bibliographie," in Fabula, http://www.fabula.org/atelier.php?L\%27auteur\%2C_une_bibliographie.

15 The function of the translator is bound up with the legal and institutional webs of discourse: the social, cultural, economic, and technological aspects of the context. Catherine Porter, "The Expository Translator," in A Companion to Translation Studies, eds. Sandra Bermann and Catherine Porter (New Jersey: Wiley Blackwell, 2014), 447.

16 Dominique Maingueneau distinguishes between three instances of authorship: a) the person b) the scrivener, and c) the writer. See Dominique Maingueneau, "Le recours à l'ethos dans I'analyse du discours littéraire" in Fabula/Les colloques, Posture d'auteurs: du Moyen Âge à la modernité, http://www.fabula.org/colloques/document2424.php; and Dominique Maingueneau, "L'èthos: un articulateur" in COnTEXTES, no. 13, 2013, http://journals.openedition.org/contextes/5772. DOI: 10.4000/contextes.5772.

17 Peter Bush and Susan Bassnett talk about the translator as an invisible mediator, on the one hand, and the translator as a celebrated artist, on the other. See Peter Bush, Susan Bassnett, "Introduction", in Susan Bassnett, Peter Bush (eds.), The Translator as Writer (London: Continuum, 2007), 1-2.
} 
However, a simple collaborative definition of translation will certainly no longer do, because, as Serenella Zanotti rightly suggested, ${ }^{18}$ the relationship between the author and the translator is still thought of in hierarchical terms as opposed to the views of an unranked heterarchy. What we greatly need, then, is to tenderly demolish this uneven rapport between them, ${ }^{19}$ in order to transform the hypotactic nature of their connection into what I would like to call an ecotactic one which includes the strategies deployed both in the publishing industry, as well in the literary field at large. Secondly, we should also focus in on the ways in which these tactics and procedures are discussed and represented in academic and professional contexts. Briefly put, we need to expand our perspectives in order to grasp the roles of the translator in the global discourse of literary value.

Translators are, indeed, building bridges between cultures, languages, and civilizations, while also linking and building novel networks of literary systems across space and time. Cultural information is, thus, traded across these vibrant social and artistic channels. Furthermore, literary authors themselves have the possibility of travelling and exchanging ideas, styles, and practices throughout the same iridescent web-like grid. This is not, then, just a method of transnationally procuring alien literary knowledge, but rather a way of defamiliarizing and reinventing one's own creative skills. Susan Basnett similarly surmises that translation is a "means not only of acquiring more information about other writers and their work, but also of discovering new ways of writing. ${ }^{20 "}$ The translator is consequently involved in more than a process of guileless indigenization, since adopting international or exotic styles of writing into one's own domestic sphere ultimately amounts to the invention of fresh literary policies.

What changes in the age of global media? It is clear that we are no longer inhabiting the same literary field and cultural environment of the late 1960s. Ecologies of knowledge can, however, account for the ways in which translators operate in a digitally globalized age because they chart that vibrant network of interacting ecosystems. ${ }^{21}$ Under the guidance of intellectuals such as Niklas

\footnotetext{
18 Serenella Zanotti, "The Translator and The Author: Two of a Kind?" in Claudia Buffagni, Beatrice Garzelli, Serenella Zanotti (eds.), The Translator as Author. Perspectives on Literary Translation (Berlin: Lit Verlag, 2011), 86-87.

19 The writer is an original and creative writer, while the translator is a mechanical imitator. See Susan Bassnett, "Writing and Translating" in Susan Bassnett, Peter Bush (eds.), The Translator as Writer (London: Continuum, 2007), 173.

20 Susan Bassnett, "Writing and Translating", in Susan Bassnett, Peter Bush (eds.), The Translator as Writer (London: Continuum, 2007), 174.

21 See Atsushi Akera, "Constructing a Representation for an Ecology of Knowledge: Methodological Advances in the Integration of Knowledge and its Various Contexts" in Social Studies of Science, vol. 37, no. 3, 2004.
} 
Luhmann, ${ }^{22}$ Pierre Bourdieu, ${ }^{23}$ or Bruno Latour, ${ }^{24}$ the translator has been gradually reconceived as a social conglomerate, including not only the translator per se, but, as previously suggested, the original author, the editor, and other cultural agents. Nonetheless, Michael Cronin compellingly argues that we need to retain an "activist dimension to the role of the translator..$^{25 \prime \prime}$ In a digital society, then, where the translator appears to be divided between local traditions and national identities, on the one hand, and international agendas, on the other, a place where the translator finds itself wedged between the patois of domestic practices and the outlandish desires and expectations of the transnational scene, a landscape where, having facilitated new and drastically improved forms of understanding of what it means to reproduce or translate a text, ${ }^{26}$ posthuman outlooks would suggest that the use and incorporation of informational technologies are, in effect, redefining the essence of the translator.

\section{The Ecology of Translation}

An expanded or upgraded definition, then, of the translator would imply a dynamic or non-binary rethinking of the notion of translatorship (translatorship is to the translator as authorship is to the author) in ecological terms: a network-distributed and technologically-driven system of interrelations between human (authors, translators, editors, reviewers, etc.) and non-human entities (professional and academic institutions, scholarships, journals, publishing houses, writing technologies, etc.) that successfully integrates all the dimensions of this global literary practice: material, ethical, and linguistic. The construction of translatorship lies, then, in the countless practices of attribution performed by the various agents that attach a translator to a corpus of texts. Translatorship symbolizes a ceremoniously recognized, multidimensional assortment of actors and practices positioned around several codified forms of ideology (value, unity, or consistence). It is, finally, a civic role conditioned by numerous events. Never before have more critical models been proposed about the concept of translation than in the last few decades. The hefty figure of theories that have been mentioned seems to be commensurate with the magnitude of contemporary translatorship itself. This diversity of methodologies and

\footnotetext{
22 Niklas Luhmann, Social Systems (Redwood City, California: Stanford University Press, 1995).

${ }^{23}$ Pierre Bourdieu, The Rules of Art: Genesis and Structure of the Literary Field (Redwood City, California: Stanford University Press, 1996).

24 Bruno Latour, Reassembling the Social. An Introduction to Actor-Network Theory (Oxford: Oxford University Press, 2005).

25 Michael Cronin, Translation and Globalization (New York: Routledge, 2006), 5.

26 See Michael Cronin, "The Translation Age: Translation, Technology, and The New Instrumentalism" in Lawrence Venuti (ed.), The Translation Studies Reader (New York: Routledge, 2012), 469-483.
} 
tactics divulges an ontological practice that is, indeed, multifarious. Therefore, the multiplicity of outlooks prevalent nowadays reveals the complex nature of translatorship, and it is more than obvious that translatorship is not a concept that can be unassumingly defined. Translatorship should not be confined to a single discipline, but rather designed as a cross-sectional study of several fields. The connections between a translator's name and his or her work could be methodically described with the help of the following elements:

A) translatorship is a textual FUNCTION: an attribute of discourses (texts are, thus, legitimized and unified);

B) translatorship revolves, at the same time, around a number of historical FIGURES: the sources of authorized texts (the issue of intellectual property rights is also salient) ${ }^{27}$;

C) translatorship is additionally represented as FORM: the visibility and/or invisibility of the translator and the other entities involved (iconography, posture, biographies);

D) translatorship, finally, is also a FORCE: its ideological, political, ethical, and commercial powers (translatorship as a form of symbolic capital, à la Bourdieu ${ }^{28}$ ).

These problems can be addressed by exploring the rich diversity of today's translation theories and practices. My solution, then, is to suggest the use of a new research methodology. Materialistic and post-anthropocentric, collective and relational, translatorship can only be accurately described through cognitive ecologies. In the age of digital globalization, the processes of translation are, first and foremost, institutionally and materially distributive or networked. Translatorship is-and has, in fact, always been-a collective, collaborative, and interactive procedure. We need to stop overlooking the importance of ecological thinking, because failing to do so will regrettably lead us to an outdated conceptualization of this defining notion of contemporary literature and culture.

\footnotetext{
${ }^{27}$ Katerina Bantinaki has convincingly argued that translators are authors to the extent that they bear direct responsibility for those aspects of the works they produce that make them what they are: translations. Consequently, she believes, translators author textual artefacts that are defined as constrained representations of literary works: Katerina Bantinaki, "The Literary Translator as Author: A Philosophical Assessment of the Idea", in Translation Studies, 2019, DOI: $10.1080 / 14781700.2019 .1668841,8-9$. It is also well worth remembering that, as Gisèle Sapiro argues in the wake of Foucault, the public production of speech was a moral issue before having become an object of labor: Gisèle Sapiro, "The Writer's Responsibility in France: From Flaubert to Sartre", in French Politics Culture \& Society, 25, no. 1 (March 2007), 1-29.

28 Pierre Bourdieu, Distinction. A Social Critique of the Judgment of Taste, transl. by Richard Nice (Massachusetts: Harvard University Press, 1987).
} 
Translatorship is, of course, subject to historical variation and this variation needs to be considered in relation to different institutions and contexts. With the help of cognitive ecologies, we can trace the fluctuating discourses that go into translation. Concisely put, this new research methodology critiques the assumptions of both ANT (actor-network theory) and translational debates, thus helping scholars to surpass what might be called the death and return of the translator dispute. The ecology of knowledge is impeccably fit to portray the diverse convolutions of today's translational phenomena, because it is capable of comprising more activities, organizations, and elements that depict the mechanics of translatorship than any other methodology available at the present moment.

As formerly intimated, translatorship does not belong (and in fact has never belonged) to a single field, not even to the general category of literary or cultural studies, and the finding - far from exposing it to a form of relativismenhances the importance of translatorship precisely by laying claim to its theoretical and methodological multiplicity. This combination-sometimes puzzling, sometimes blatantly contradictory-can be managed, though, through the use of said ecologies of knowledge. Each translational ecosystem comprises a sequence of interconnected components: technologies, actors, materials, media, networks, objects, spaces, information, strategies, genres, institutions, activities, etc. Far from representing a topic that can be studied within the confines of a single level and in a lone direction, translatorship instead infers the re-dimensioning of its subsystems in a genuine ecology of knowledge.

One could do worse than acknowledge the fact that all ecosystems can be fashioned, as Douglas Eyman fittingly proposed in one of his books, ${ }^{29}$ in terms of scale. Thus, by adapting this terminological suggestion, I would claim that translational ecologies - and their circulation-might also be thought of in terms of size: 1) micro-ecologies: they describe the level or the work of a single translator, for instance, in isolation, but it could also include the instruments and the materials used by the translator and his or her relationship with the original author or the editor; 2) mezzo-ecologies (collaborative translations, for instance), and, finally, 3) macro-ecologies: this involves institutions, discursive fields, scholarly disciplines, nations, literary history, canons, and so on. This is closely related, I would add, to the ways in which Eric Hayot, for instance, defines the concept of literary 'worlding' as a scale with both artistic and contextual features. ${ }^{30}$

29 Douglas Eyman, Digital Rhetoric: Theory, Method, Practice (Ann Arbor: University of Michigan Press, 2015), DOI: http://dx.doi.org/10.3998/dh.13030181.0001.001.

30 See Eric Hayot, On Literary Worlds (Oxford: Oxford University Press, 2012). 


\section{The Translator as World Author}

The translator is responsible for the ways in which books and authors travel abroad but also for how they foster various worlds and collide with or even change others. The translator is, thus, an agent of global circulation fostering a sense of interconnectedness. We have seen, however, that an expanded understanding of the translator presupposes the existence and collaboration of a series of interlinked political, economic, and ethical ecosystems. My suggestion is that, in trying to understand the worlding quality of translatorship, we should always think about how human and non-human agents interact within this process of intercultural transference. Translators are essential elements in the production and distribution of world literature. Translatorship belongs to the world because it includes "the multiplicity of agency that sets in as soon as one person's imaginary literary world enters into a relationship with any aspect of the much larger, all-encompassing 'real world' of which it is, inherently, a part. ${ }^{31 "}$ My argument is, then, twofold: on the one hand, I contend that, in ecological terms, the translator is part and parcel of the concept of authorship, while, on the other hand, I also want to argue that it is the translator itself, really, that lends authorship its worldly dimension. Translatorshipunderstood, here, in terms of an ecosystem-connects the imaginary or fictional world of a text with the real worlds through which it voyages.

World translatorship can be consequently defined as the ecological coexistence and interaction of all the practices and entities included in the process of circulating a text throughout the globe. We have seen plenty of theories about how translators might or might not be identified or codified within their translated work, but what is necessary in the $21^{\text {st }}$ century, however, is a better understanding of how the task of the translator looks like in a worldly context or in a wider range of transnational and international contexts. The function of the translator needs to be expanded to include not only a sociology, but, as I have continually suggested, an ecology of writers, readers, visual artists, editors, publishers, agents, institutions, librarians, and other literary professionals. Translatorship, thus, reiterates a literary text across a variety of different worldly ecosystems steeped in quite particular circumstances of material production and circulation. Redefining the translator as a world author entails, then, the existence of a "multiply interconnected network of people, texts, and diverse cultural traditions" ${ }^{32}$. What is, however, paramount is to once more stress, as previously suggested, the fact that an ecological approach is

${ }^{31}$ Rebecca Braun, "Introduction. Twenty-First-Century Approaches to World Authorship" in Tobias Boes, Rebecca Braun, Emily Spiers (eds.), World Authorship (Oxford: Oxford University Press, 2020), 4.

32 Ibid., 10. Also see Rebecca Walkowitz, Born Translated: The Contemporary Novel in an Age of World Literature (New York: Columbia University Press, 2015). 
capable of upholding a balanced and equal relationship between all the elements and actors involved in the process of translation.

\section{Conclusions}

Simply put, the literary work always already has a composite multiplicity of authors, but, when the idea of transporting the same text from point $A$ to point $B$ comes into play, however, its circulation through various cultures and geopolitical contexts suddenly becomes even more important and, thus, highlights the crucial role of all the other world-agents involved. Projected either as a theory or as a practice, translatorship-an equivocal concept relentlessly wavering between fame and obscurity-has undertaken vital changes in recent times. Translatorship is a flexible and multifaceted idea contingent on the innumerable circumstances in which it maneuvers. It therefore cannot be enclosed in a simple definition but, as we have seen, by means of a broad gamut of cultural indicators. Translatorship is collective, global, plural, distributive, and networked. In order to make room for all the aspects of literary interpretation, translation studies ought to implement the ecological definition of the translator. 